American Journal of Applied Sciences 6 (12): 2050-2053, 2009

ISSN 1546-9239

(C) 2009 Science Publications

\title{
Helicobacter pylori Colonization in Biopsies of the Adenotonsillectomy Specimens
}

\author{
${ }^{1}$ M.J. Zahedi, ${ }^{1}$ S. Darvish Moghadam, ${ }^{2}$ M. Ahmadi Mosavi, \\ ${ }^{3}$ T. Mirshekari and ${ }^{1}$ M. Hayatbakhsh \\ ${ }^{1}$ Department of Gastroenterology, \\ ${ }^{2}$ Department of Ear, Nose and Throat, \\ ${ }^{3}$ Department of Pathology, \\ Medical School and Physiology Research Center, Kerman, Iran
}

\begin{abstract}
Problem statement: Helicobacter pylori (H. pylori) is a microaerophilic, gram negative bacillus, which can cause peptic ulcer and gastric cancer. Recurrent infection with this agent is considered as one of the reasons for failure of peptic ulcer treatment. Some studies have reported colonization of $\mathrm{H}$. pylori in dental plaques, tonsils and adenoid tissues. Therefore oral cavity could be the source of $\mathrm{H}$. pylori and it might be the reason for unsuccessful eradication. Approach: In this cross sectional study, 95 patients with the average age of $12.1 \pm 7.5$ years undergoing adenotonsillectomy were chosen consecutively. Intra-operatively a $2 \mathrm{~mm}$ section of the tonsils were removed and investigated for H. pylori by Rapid Urease Test (RUT). Post-operatively the removed tonsils were stained by hematoxylin-eosin ( $\mathrm{H}$ and $\mathrm{E}$ ) and Gimsa for direct investigation of $H$. pylori bacterium. Serum samples of the patients were also tested for the presence of $H$. pylori $\operatorname{IgG}$ antibody. Results: Overall 70 patients (73.7\%) had positive anti- H. pylori IgG antibody in their sera. The results of RUT on adeno-tonsils showed that $42.1 \%$ of the specimens were positive for $H$. pylori. In histology examination, 9 patients (9.5\%) were positive for the presence of bacterium. Conclusion: Based on our findings it seems that tonsils and adenoid tissues are the candidate places for the growth of $H$. pylori. Further studies about the role of tonsillar colonization of $\mathrm{H}$. pylori in re-infection after treatment are recommended.
\end{abstract}

Key words: Helicobacter pylori colonization, adenotonsils, adenotonsillectomy

\section{INTRODUCTION}

Helicobacter pylori, is a worldwide bacterial infection that has a prevalence of $30 \%$ in developed to $90 \%$ in underdeveloped countries ${ }^{[1,2]}$. It is reported that the prevalence rate in Iran is between $50-90 \%{ }^{[3]}$. This microaerophilic, gram negative rod is found mostly between epithelial surface and gastric mucus layer. Despite adherence of $H$. pylori to gastric epithelial cells, it can not enter into the epithelium. The enzymes urease, catalase and lipase produced by the bacterium may play some roles in pathogenesis of $H$. pylori induced gastrointestinal diseases ${ }^{[4,5]}$. Fecal-oral is the main route of transmission for H. pylori, however the bacteria can be transmitted through saliva as well ${ }^{[6]}$. Infection due to $H$. pylori causes gastritis, peptic ulcer, Mucosa Associated Lymphoid Tissue (MALT) lymphoma and gastric carcinoma ${ }^{[7]}$. Some studies have reported colonization of $H$. pylori in dental plaques, tonsils, saliva and adenoid tissues ${ }^{[8,9]}$. Considering the fecal-oral route transmission of $H$. pylori and its presence on the tonsils, it is possible that these organs have a potential role in colonization and transmission of the bacteria ${ }^{[9,10]}$.

In treated patients the recurrence rate of peptic ulcer without eradication of $H$. pylori reaches to $70 \%$, while with eradication of the infection this rate will reduce to $20 \%{ }^{[11]}$. Re-infection with the new bacterium after eradication is unusual, however recrudescence of the infection with the same organism may occurs frequently ${ }^{[11,12]}$. In this respect another source of infection other than stomach might be involved ${ }^{[10]}$. Minocha has shown reduced colonization of $H$. pylori infection in coming years after surgical adenotonsillectomy ${ }^{[13]}$. Based on the reports of few studies with contradictory results, it has proposed that adeno- tonsils might be a source of $H$. pylori colonization. Accordingly this study was designed to detect colonization of $H$. pylori in the biopsy specimens of adenotonsil tissues in scheduled surgical patients.

Corresponding Author: Sodaif Darvish Moghadam, Department of Gastroenterology and Physiology Research Center, Kerman University of Medical Sciences, Kerman, Iran Tel: +989131403937 


\section{MATERIALS AND METHODS}

Patients and methods: This cross-sectional study was performed on 95 patients who scheduled for adenotonsillectomy in Ear, Nose and Throat (ENT) ward of Shafa hospital (Kerman school of medical sciences) during the year 2007. All of these patients had common indications for adenotonsillectomy including recurrent tonsillitis, chronic tonsillitis and/or adenoiditis. None of the patients had received any antibiotic or gastric acid-lowering drugs during the last 2 weeks prior to surgery. All of the parents and/or patients agreed for surgery and the study proposal.

H. pylori diagnosis: $H$. pylori tonsil colonization was diagnosed based on Rapid Urease Test (RUT) and histopathology on the adeno-tonsil tissues. Before removing the adeno-tonsils, a three millimeter biopsy specimen was taken from these tissues during general anesthesia with a sterile punch device washed with normal saline. The specimens were kept in rapid urease test solution tubes at room temperature. Results were recorded during $4 \mathrm{~h}$ after the test. Yellow and red color solutions were considered as negative and positive results respectively. After surgery the taken tonsils were put in $10 \%$ formalin and transferred to the pathology ward for histopathology examination. In this part samples were sectioned and stained with hematoxylin and eosin ( $\mathrm{H}$ and $\mathrm{E}$ ) and Gimsa. The processed specimens were examined by the pathologist. Serum samples of the patients were also tested for the presence of $H$. pylori $\mathrm{IgG}$ antibody by using quantitative enzyme immunoassay (EIA) (Monobind 1425-300 USA).

Statistical analysis: The analysis was based on SPSS 11.5 software with $95 \%$ confidence intervals $(95 \% \mathrm{CI})$. Also Chi square and paired t-test were used for statistical analysis.

\section{RESULTS}

Ninety five patients including 50 females and 45 males were studied. Their average of age was $12.1 \pm 7.5$ years with a range between 2-35 years. The average of the age in females was 3.5 years more than males $(p=0.018)$.

In this study variables included: sex, patients' level of education, income of the family, residence (place of stay) and level of education of the fathers (Table 1). No relationship was found between these variables and colonization of $H$. pylori in adeno- tonsil tissues.

Duration of pharyngeal symptoms in these patients was 1 month to 27 years. Most of them (54.7\%) had their symptoms for 1-5 years. The common surgical findings were inflamed adeno-tonsils with or without blockage. In biopsy specimens, RUT was positive in 40 cases (42.1\%). In histology examination, bacteria were observed in adeno-tonsil tissues in 9 patients $(9.5 \%)$. The serology test for $H$. pylori IgG antibody was positive in $70(73.7 \%)$ of the patients. Seventeen patients (17.9\%) had history of stomach upset (Table 2). H. pylori serology was positive in 15 of 17 (88.2\%) symptomatic patients, while it was positive in 56 of 78 (71.8\%) asymptomatic cases $(\mathrm{p}=0.007)$.

\begin{tabular}{llcc}
$\begin{array}{l}\text { Table 1: Demographic features } \\
\text { adenotonsillectomy (N=95) }\end{array}$ & in & patients & undergone \\
\hline Variable & Group & Number & Percent \\
\hline Sex & Female & 50 & 52.6 \\
Education & Male & 45 & 47.4 \\
& Uneducated & 1 & 1.1 \\
& Preliminary & 29 & 30.5 \\
& Primary school & 31 & 32.6 \\
& High school & 25 & 26.3 \\
& Diploma & 4 & 4.2 \\
& University student & 2 & 2.1 \\
& Bachelor (of degree) & 2 & 2.1 \\
& Master of Science & 1 & 1.1 \\
Monthly income & Low & 56 & 59.0 \\
& Medium & 35 & 36.8 \\
Residence & High & 4 & 4.2 \\
& City (urban) & 46 & 48.4 \\
Father s education & Village (rural) & 49 & 51.6 \\
& Uneducated & 22 & 23.2 \\
& Primary school & 14 & 14.7 \\
& High school & 31 & 32.6 \\
& Diploma & 20 & 21.0 \\
& Tow years after diploma & 1 & 1.1 \\
& Bachelor (of degree) & 6 & 6.3 \\
& Ph.D. & 1 & 1.1 \\
\hline
\end{tabular}

Table 2: The frequency of symptoms and findings in patients undergone adenotonsillectomy $(\mathrm{N}=95)$

\begin{tabular}{|c|c|c|c|c|c|c|}
\hline Variable & Group & Female frequency & Percent & Male frequency & Percent & p-value \\
\hline \multirow[t]{2}{*}{ Digestive sign } & Negative & 36 & 46.2 & 42 & 53.8 & 0.007 \\
\hline & Positive & 14 & 82.4 & 3 & 17.6 & \\
\hline \multirow[t]{3}{*}{ Duration of pharynges symptoms } & $<1$ year & 10 & 47.6 & 11 & 52.4 & 0.030 \\
\hline & $1-5$ years & 23 & 44.2 & 29 & 55.8 & \\
\hline & $>5$ years & 17 & 77.3 & 5 & 22.7 & \\
\hline \multirow[t]{3}{*}{ Surgery (indication) finding } & Inflammation & 12 & 60.0 & 8 & 40.0 & 0.700 \\
\hline & Blocking & 24 & 49.0 & 25 & 51.0 & \\
\hline & Both & 14 & 53.8 & 12 & 46.2 & \\
\hline \multirow[t]{2}{*}{ Rapid urease test } & Negative & 29 & 52.5 & 26 & 47.5 & 0.98 \\
\hline & Positive & 21 & 52.5 & 19 & 47.5 & \\
\hline \multirow[t]{2}{*}{ Serology for $H$. pylori } & Negative & 13 & 52.0 & 12 & 48.0 & 0.941 \\
\hline & Positive & 37 & 52.9 & 33 & 47.1 & \\
\hline \multirow[t]{2}{*}{ Histology for H. pylori } & Negative & 45 & 52.3 & 41 & 47.7 & 0.854 \\
\hline & Positive & 5 & 55.6 & 4 & 44.4 & \\
\hline
\end{tabular}




\section{DISCUSSION}

H. pylori is a world wide distributed chronic infection which is associated with gastritis, peptic ulcer, gastric carcinoma and lymphoma. In developing countries most of the children are affected by this bacterium up to the age of 10 as the infection rate will reach $80 \%$ at the age of 50 . A significant number of these subjects do not show any obvious clinical symptoms ${ }^{[14]}$. Stomach is the main place of $H$. pylori colonization and the eradication of infection from the stomach is the mainstay of therapy for prevention of peptic ulcer recurrence. It has been shown that by eradication of $H$. pylori, peptic ulcer recurrence will be reduced to less than $10 \%$ annually or even it may result in MALT regression ${ }^{[15]}$. Re-infection or bacterial reactivation is an important factor in recurrence of peptic ulcer. The re-infection rate in different studies has been reported from $1 \%$ to $20 \%$ annually ${ }^{[16]}$. Among the factors related to infection recurrence or colonization, mouth cavity is the issue which has been doubted and argued by the researchers. This hypothesis was propounded when some studies have shown the colonization of $\mathrm{H}$. pylori in dental plaques, tonsils and adenoid tissues ${ }^{[8,9]}$. In our study, serology test was positive in $73.7 \%$ of patients revealing high rate of infection in the first and second decades of life. RUT was positive in $42 \%$ of patients and histology showed bacterium in $9.5 \%$ of the samples. In Yilmaz et al study from Turkey on 50 samples of adenotonsillectomy in children aged 2-10 years, the results of $H$. pylori serology was positive in $50 \%$ of cases but none of the surgical samples were positive for rapid urease test ${ }^{[17]}$. The results of another study from Turkey on 19 patients by Unver et al showed that rapid urease test was positive in $57.8 \%$ of adenotonsillectomy samples ${ }^{[18]}$. In addition, in another study carried out by Aslan on 52 patients, pronto dry test, which shows $H$. pylori infection, was positive in $42 \%$; however, no $H$. pylori was found in $\mathrm{H}$ and $\mathrm{E}$ staining ${ }^{[19]}$. The difference of results in various studies might be due to different laboratory methods but the positive results of urease test or histology in some of these studies reflect the existence of $H$. pylori on adeno-tonsil tissues. In our study, RUT was positive in $42.1 \%$ of cases while histology was positive just in $9.5 \%$ of samples. This difference might be explained by the possible existence of other urease producing bacteria in the mouth or adeno- tonsil tissues. Also it's possible that H. pylori may contaminate the oral cavity temporarily or invade the adeno-tonsil tissues superficially, in contrast of its permanent and deep replacement in gastric mucosa.

\section{CONCLUSION}

Existence of $H$. pylori shown by RUT and in some histology findings potentiate the hypothesis that this bacterium might be able to live in oral cavity, where it can be regarded as one of the infection resources and may play a role in oral transmission of this common bacterium.

\section{ACKNOWLEDGEMENT}

Kindly cooperation of Research Deputy of Kerman University of Medical Sciences and Physiology Research Center in conducting this study is appreciated.

\section{REFERENCES}

1. Baldwin, D.N., B. Shepherd, P. Kraemer, M.K. Hall and L.K. Sycuro et al., 2007. Identification of Helicobacter pylori genes that contribute to stomach colonization. Infect. Immunol., 75: 1005-1016. DOI: 10.1128/IAI.01176-06

2. Magalhaes Queiroz, D.M. and F. Luzza, 2006. Epidemiology of Helicobacter pylori infection. Helicobacter, 11: 1-5. http://direct.bl.uk/bld/PlaceOrder.do?UIN=193702 $725 \&$ ETOC $=$ RN\& from $=$ searchengine

3. Hashemi, M.R., M. Rahnavardi, B. Bikdeli and M. Dehghani Zahedani, 2006. H. pylori infection among 1000 southern Iranian dyspeptic patients. World J. Gastroenterol., 12: 5479-5482. http://www.ncbi.nlm.nih.gov/pubmed/17006984

4. Beswick, E.J., I.V. Pinchuk, G. Suarez, J.C. Sierra and V.E. Reyes, 2006. Helicobacter pylori CagAdependent macrophage migration inhibitory factor produced by gastric epithelial cells binds to CD74 and stimulates procarcinogenic events. J. Immunol., $\quad$ 176: 6794-6801. http://www.jimmunol.org/cgi/content/abstract/176/ $11 / 6794$

5. Lin, Y.F., C.Y. Chen, M.H. Tsai, M.S. Wu, Y.C. Wang, E.Y. Chuang et al., 2007. Duodenal ulcer-related antigens from Helicobacter pylori: Immunoproteome and protein microarray approaches. Mol. Cell Proteom., 6: 1018-1026. http://www.mcponline.org/cgi/content/abstract/6/6/1018

6. Mladenova, I., M. Durazzo and R. Pellicano, 2006. Transmission of Helicobacter pylori: Are there evidences for a fecal-oral route? Minerva Med., 97: 15-18. http://www.ncbi.nlm.nih.gov/pubmed/16565693 
7. Sagaert, X., C. de Wolf-Peeters, H. Noels and M. Baens, 2007. The pathogenesis of MALT lymphomas: Where do we stand? Leukemia, 21: 389-396. http://www.ncbi.nlm.nih.gov/pubmed/17230229

8. Gebara, E.C., C.M. Faria, C. Pannuti, L. Chehter, M.P. Mayer and L.A. Lima, 2006. Persistence of Helicobacter pylori in the oral cavity after systemic eradication therapy. J. Clin. Periodontol., 33: 329-333. http://www.ncbi.nlm.nih.gov/pubmed/16634953

9. Bulut, Y., A. Agacayak, T. Karlidag, Z.A. Toraman and M. Yilmaz, 2006. Association of cagA+ Helicobacter pylori with adenotonsillar hypertrophy. Tohoku J. Exp. Med., 209: 229-233. http://www.ncbi.nlm.nih.gov/pubmed/16778369

10. Jelavic, B., M. Bevanda, M. Ostojic, M. Leventic, M. Vasilj and E. Knezevic, 2007. Tonsillar colonization is unlikely to play important role in Helicobacter pylori infection in children. Int. J. Pediatr. Otorhinolaryngol., 71: 585-590. http://www.ncbi.nlm.nih.gov/pubmed/17239446

11. Bose, A.C., V. Kate, N. Ananthakrishnan and S.C. Parija, 2007. Helicobacter pylori eradication prevents recurrence after simple closure of perforated duodenal ulcer. J. Gastroenterol. Hepatol., 22: 345-348. http://www.ncbi.nlm.nih.gov/pubmed/17295765

12. Saad, R.A., 2006. Re-infection following successful eradication of Helicobacter pylori infection. Aliment Pharmacol. Ther., 24: 695-696. http://www.ncbi.nlm.nih.gov/pubmed/16907902

13. Minocha, A., C.A. Raczkowski and R.J. Richards, 1997. Is a history of tonsillectomy associated with a decreased risk of Helicobacter pylori infection? J. Clin. Gastroenterol., 25: 580-582. http://www.ncbi.nlm.nih.gov/pubmed/9451666
14. Das, J.C. and N. Paul, 2007. Epidemiology and pathophysiology of Helicobacter pylori infection in children. Indian J. Pediatr., 74: 287-290. http://www.ncbi.nlm.nih.gov/pubmed/17401270

15. Komoto, M., K. Tominaga, B. Nakata, T. Takashima, T. Inoue and K. Hirakawa, 2006. Complete regression of low-grade Mucosa-Associated Lymphoid Tissue (MALT) lymphoma in the gastric stump after eradication of Helicobacter pylori. J. Exp. Clin. Cancer Res., 25: 283-285. http://www.ncbi.nlm.nih.gov/pubmed/16918142

16. Cameron, E.A., G.D. Bell, L. Baldwin, K.U. Powell and S.G. Williams, 2006. Long-term study of reinfection following successful eradication of Helicobacter pylori infection. Aliment Pharmacol. Ther., 23: 1355-1358. http://www.ncbi.nlm.nih.gov/pubmed/16629941

17. Yilmaz, M., C.O. Kara, I. Kaleli, M. Demir, F. Tumkaya and A.S. Buke et al., 2004. Are tonsils a reservoir for Helicobacter pylori infection in children? Int. J. Pediatr. Otorhinolaryngol., 68: 307-310. http://www.ncbi.nlm.nih.gov/pubmed/15129940

18. Unver, S., U. Kubilay, O.S. Sezen and T. Coskuner, 2001. Investigation of Helicobacter pylori colonization in adenotonsillectomy specimens by means of the CLO test. Laryngoscope, 111: 2183-2186. http://www.ncbi.nlm.nih.gov/pubmed/11802022

19. Aslan, S., I. Yilmaz, N. Bal, M. Sener, R. Butros and B. Demirhan et al., 2007. Investigation of Helicobacter pylori in tonsillary tissue with pronto dry test and pathologic examination. Auris Nasus Larynx, 34: 339-342. http://www.ncbi.nlm.nih.gov/pubmed/17196780 